\title{
Justice and Equality for All? Proportional Representation in Belgium and France (1883-1921) ${ }^{1}$
}

\author{
Justiça e Igualdade para Todos? Representação Proporcional na Bélgica e na \\ França (1883-1921)
}

\section{Frederik Dhondt ${ }^{1}$}

Vrije Universiteit Brussel, Ghent University, Belgium

\begin{abstract}
Whereas $19^{\text {th }}$ century Belgium is traditionally framed as heavily dependent on France, this image ought to be nuanced for its political system. During what Pierre Rosanvallon named the transnational 'proportional moment' (1899-1914), the introduction of Proportional Representation in parliamentary elections generated a French interest in Belgium as the 'electoral laboratory of Europe'. Arguments raised in the French Chambre des Députés were similar to those used in Belgian Parliament. The present article addresses the structural differences between the electoral debate in both states. Whereas Belgian constitutional doctrine adapted smoothly to the introduction of proportionality (Oscar Orban/Paul Errera) and held a moderate position bordering on that of Hans Kelsen, French doctrine was divided between the Parisian Adhémar Esmein, who defended the majority system as the bedrock of republicanism, and provincial professors of constitutional law, who had corporatist ideas, or were in favour of judicial review (JosephBarthélémy, Léon Duguit).
\end{abstract}

Keywords: Constitutional Law. Electoral Law. Public Law. Belgian Legal History. French Legal History.
Resumo: Enquanto a Bélgica do século XIX é tradicionalmente enquadrada como dependente da França, essa imagem possui uma nuance diversa no que se refere ao seu sistema político. Durante o que Pierre Rosanvallon chamou de "momento proporcional" transnacional (18991914), a introdução da representação proporcional nas eleições parlamentares gerou um interesse francês na Bélgica como o "laboratório eleitoral da Europa”. Os argumentos levantados na Câmara dos Deputados francesa foram semelhantes aos usados no Parlamento belga. O presente artigo aborda as diferenças estruturais entre o debate eleitoral nos dois Estados. Enquanto a doutrina constitucional belga se adaptou suavemente à introdução da proporcionalidade (Oscar Orban/ Paul Errera) e manteve uma posição moderada próxima à posição de Hans Kelsen, a doutrina francesa foi dividida entre o parisiense Adhémar Esmein, que defendia o sistema majoritário como a base do republicanismo, e os professores locais de direito constitucional, que tinham ideias corporativistas ou eram a favor da revisão judicial (Joseph-Barthélémy, Léon Duguit).

Palavras-chave: Representação Proporcional. Eleições Parlamentares. Sistema Majoritário. Revisão Judicial.

${ }^{1}$ My thanks to the auditors and participants of the 2019 British Legal History Conference: Comparative Legal History (St Andrews, 10-13 July 2019) for their comments on an earlier draft, as well as to Yves Deroubaix and Matthias Boydens for proofreading.

Recebido em: 28/04/2020

Revisado em: $17 / 11 / 2020$

Aprovado em: 03/12/2020 


\section{Introduction}

Suum cuique. A chacun sa part

$(\text { ORBAN, 1911) })^{2}$

The current crisis of political representation in the West leads to calls for electoral reform. Often, the majority system is seen as the source of unease and voter dropout. Proportional representation would be more able to reconcile citizens with representative democracy, bringing society closer to politics, or allowing for a national consensus mirroring the diversity of linguistic or ethnic groups. ${ }^{3}$ When it comes to implementing reforms in majority systems, however, the ardours are far more timid. Emmanuel Macron repeatedly hinted at the introduction of a 'dose de proportionnelle' for the election of the Assemblée Nationale. At the establishment of the Fifth Republic in 1958, the majority system was felt as a necessary guarantee against the disorders of the Fourth Republic, which was for the major part of its existence characterised by political fragmentation, reinforced by a proportional attribution of seats ${ }^{4}$.

The recent crisis of political representation has questioned the selfevident advantages of majority systems, but the reverse is also true, as the protracted institutional crisis in Belgium (2007-2008, 2010-2012, 2018-2020) or the crisis in Spain $(2016,2019)$ are sometimes ascribed to the fragmentation following from proportional representation. More reactionary $19^{\text {th }}$ century criticism associated proportional representation with heresy, since it put 'truth' and 'error' on the same footing 5

${ }^{2}$ Orban (1911) I, 46; see Bouhon (2019).

${ }^{3}$ Rosanvallon (2010, p. 163).

${ }^{4}$ Le Beguec (1986); Rouvillois (2000). For an analysis of the effect of a 'dose de proportionnelle', see Cohendet et al. (2019).

${ }^{5}$ Orban (1911, I, p. 71). 
Advantages and disadvantages of proportional representation ${ }^{6}$ and majority voting are classics of political science. The present paper is concerned with the constitutional debate in France and Belgium at the turn of the century, when proportional voting was introduced for Belgian parliamentary elections (1899) and in France (1919). The 'D'Hondt system', designed by the Ghent professor of Civil Law Victor D'Hondt (1841-1901), became one of the most popular formulas for seat attribution in the world. ${ }^{7}$ Although conceptions of justice in power relations between political parties dominate the debate, constitutional lawyers framed the discussion using the concept of national representation and constitutional government. This debate is also an occasion to nuance the overall image of Belgian dependence on France. ${ }^{8}$

The major difference from the start is the French early adoption of universal suffrage for men. After the experiment of the Convention in 1792, universal suffrage returned for good with the Revolution of 1848. Belgium, by contrast, only abolished censitary suffrage in 1893 for parliamentary elections, and did not introduce the 'one man, one vote' principle before 1918, under the pressure of World War One. ${ }^{9}$ From 1893 to 1918, parliamentary suffrage was 'plural'. ${ }^{10}$ All male

${ }^{6}$ Carré de Malberg rejects the very notion of proportional 'representation', and only considers proportional 'elections' to be theoretically conceivable, since - in his theory of national sovereignty - the collective corpus of voters is represented by parliament, not the individual voter. Hence, PR would constitute an 'atteinte' and a 'deformation' to representative democracy. Carré De Malberg (1922), II, 468-469, 474. On the other hand, Carré de Malberg recognised that the majority system created an aberration: if one of the competing parties would be guaranteed to govern alone, this would diminish the country's right to translate its appreciation of policy into the electoral result. ibid 473-474, note 3 .

${ }^{7}$ D'Hondt would have 'reinvented' the calculation method used by Thomas Jefferson to apportion seats in the House of Representatives, according to GASSNER (1993), 1,7. D'HONDT (1882). See also GOBLET D'ALVIELLA (1900).

${ }^{8}$ HEIRBAUT and STORME (2006), 3.

9 VELAERS (2009); GILISSEN (1958). On the restrictions applicable to Universal Suffrage in France 1848-1849, see BLACHÈR (2013).

${ }_{10}$ Similar systems existed in England up to 1894 for the elections of the boards of guardians of the poor, in Swedish local elections, in New South Wales (Australia) and in local government in Eastern Prussia. John Stuart Mill advocated a supplementary vote for electors with a degree. Orban (1911) I, 35; Errera (1916), 139-140. 
inhabitants aged 25 or more ${ }^{11}$ had one vote (which they were obliged to cast). ${ }^{12}$ Beneficiaries of a university degree or appointed in a higher administrative function benefited from two extra votes and were thus 'triple voters'. ${ }^{13}$ Those over $25^{14}$ who either paid a rent tax of five francs ${ }^{15}$ or owned their lodging had the right to an extra vote. ${ }^{16}$ Married men of at least 35 or widowers with a legitimate descent could equally claim an extra vote. ${ }^{17}$ In total, no individual could vote more than three times.

Furthermore, in Belgium, the Catholic Party ruled with an absolute majority from 1884 to 1914, irrespective of the introduction of proportional voting. ${ }^{18}$ The perceived vicissitudes of the D'Hondt system have recently been denounced for the election of MEP's in Britain. ${ }^{19}$

\footnotetext{
${ }^{11}$ This age had been lowered to 21 in 1870. Barthélémy (1912), 322.

12 This obligation still exists under Belgian law. See articles 207 to 210 of the Belgian Electoral Code of 12 April 1894, Moniteur Belge 15 April 1894. ORBAN (1911) I, 28.
}

${ }^{13}$ ERRERA (1916), 145-146. For this condition, no distinctions were operated between public and private institutions of higher education, as a consequence of the freedom of education enshrined in article 17 of the 1831 constitution. A university degree was not necessarily required, as certificates of attendance at a 'full course' of secondary education of the higher degree were accepted as well. The administrative offices mentioned were those of governor, diplomat, member of the Royal Academy, lawyer, notary, doctor, top class civil servant, director of a scientific institution, teachers, priest... See PANTENS (1901), 44-49.

${ }^{14}$ For the Belgian Senate, 30 (art. 53 Constitution). ERRERA (1916), 146.

${ }^{15}$ This tax was calculated on the rent value of a lodging, on doors and windows and on furniture. Not the amount of tax in itself, but 'la présomption d'ordre social, attachée à la possession des bases mêmes de cet impôt' generated the right to the privilege of a supplementary vote. ibid 144.

${ }^{16}$ Property owned by wives (or minor children) was counted together with that of their husbands. Ownership of an immovable worth over 2000 Belgian Francs (generating a cadastral, government-estimated rent income of 48 francs) or of a government bond annually generating more than 100 Belgian Francs of rent (art. 47 (old) Constitution, paragraph $\left.2,2^{\circ}\right)$.

${ }^{17}$ ERRERA (1916), 143. Or, to be more precise, paying more than 5 Belgian Francs in the habitation tax (art. 47 (old), paragraph 2, $1^{\circ}$ ).

${ }^{18}$ LAMBERTS \& LORY (eds) (1986).

19 In the run-up to the 2019 European Parliamentary elections, public intellectual Richard Dawkins called the D'Hondt system 'ludicrous' (sic). See https://twitter.com/ RichardDawkins/status/1130363649623777280 
These criticisms are often ill-informed. ${ }^{20}$ Another factor, district size, hampers the proportional character of seat attribution, especially when it comes to the last seats. We will come back to this point, which will highlight the essential innovation of the 1919 reform of seat attribution rules in Belgium. In contrast to Catholic and conservative Belgium, the French Third Republic was ruled by left-wing politicians as Jules Ferry (1832-1893) and Aristide Briand (1862-1932), introducing reforms such the law of separation between Church and State in 1905. Yet, the majority system did not produce stable political configurations: from 1870 to 1914 , France had no less than thirty-three successive governments. ${ }^{21}$

In spite of these stark contrasts, Belgium and France have been inextricably linked in their legal culture. ${ }^{22}$ This has lead prominent Belgian scholars to state that the country had become 'dominated by France' from the Napoleonic period on..$^{23}$ Belgian $19^{\text {th }}$-century elites, including legal elites, spoke French. ${ }^{24}$ French political news dominated the frontpage of the main journals, the Liberal Indépendance belge and the Catholic Journal de Bruxelles. ${ }^{25}$

The major legal study on this topic has been written by a notorious figure of French legal academy: Joseph Barthélémy (1874-1945) ${ }^{26}$. His work L'organisation du suffrage. L'expérience belge (1912) lauded

(last accessed 21 October 2019).

${ }^{20}$ See Brandenburg 2019. One could however object, following Oscar Orban that 'fanatic proponents of PR would sacrifice anything to the mathematical objective [...] scrapping any remaining vote losses to arrive either at a single electoral college $[\ldots]$ This is unacceptable. When one is everybody's MP, elected by citizens spread all over the country, one is nobody's MP in reality.' ORBAN (1911) I, 45.

${ }^{21}$ HOUTTE (2014); RÉMOND (2013).

${ }^{22}$ SOLEIL (2014); LESAFFER \& VAN ERP (eds.) (2008).

${ }^{23}$ HEIRBAUT and STORME (2006), 649.

${ }^{24}$ VAN GOETHEM (1990). At university level, contacts existed with the United Kingdom, Germany and Austria. Especially German academics had been highly influential at the universities of Ghent, Brussels, Louvain and Liège. See DHONDT (2012).

${ }^{25}$ VANDER VORST ZEEGERS (1965).

${ }^{26}$ BARTHÉLÉMY (1912); MARTINEZ (1998), 28 ; SAULNIER (2004). 'un modèle d'exactitude, de clairvoyance, d'impartialité', according to VAUTHIER (1912), 564 
the combination of proportional representation and plural voting. ${ }^{27}$ Barthélémy's interest in this specific Belgian combination, however, cannot be seen separate from the major difference highlighted above: Belgium did not have universal suffrage, on which the French Third Republic's parliamentary system was founded.

\section{Electoral Reform Before the Great War}

In this section, electoral reform before the Great War will be discussed.

\subsection{Belgium 1883: capacity suffrage for local elections, or a failed attempt to contain the rise of universal suffrage}

In 1883, the liberal government headed by Walthère FrèreOrban proposed to Parliament to enlarge municipal suffrage. Local and provincial suffrage was governed by the law, and not by the Constitution, which made it the ideal locus of experiments. ${ }^{28}$ Earlier (Law of 12 June 1871), Catholic governments had attempted to transform their party's domination of social life into political power by expanding census requirements in local elections. Under Frère-Orban's reform, a system based on local taxation would be linked to the obtention of a degree of lower education. ${ }^{29}$ This system had been claimed for twenty years by

\footnotetext{
${ }^{27}$ See equally Carré de Malberg's remark that plural voting would not necessary violate the principle of equal treatment between citizens. According to this famous defender of national sovereignty, voting rights ought to be exercised in the national, collective interest, and were not strictly individual, since he considered individual citizens not to have part in the exercise of sovereignty. CARRÉ DE MALBERG (1922), II, 471-472. ${ }^{28}$ BARTHÉLÉMY (1912), 12. In the same sense, Joseph Lebeau in the National Congress: 'l'éducation du peuple sera faite par les élections municipales et provinciales'. ibid 42.

${ }^{29}$ In the Constituent Assembly (National Congress) of 1830-1831, capacity was seen as a 'privilege', violating political equality among Belgian citizens, all (theoretically) capable of attaining the censitary threshold. BARTHÉLÉMY (1912), 25. The Liberal government sought reassurance in restricting the enlargement of the electoral corps to those who had graduated from an official, state institution. A supplementary check of degrees obtained in Catholic institutions, by an independent committee, was judged mandatory by the Liberal majority, but abandoned in the end as a violation of the principle of freedom of education. The Liberals reacted to an earlier reform (1871) whereby the Catholic majority
} 
local Liberal sections, as a 'barrière infranchissable' against universal suffrage. ${ }^{30}$ Catholics loathed it as a Chinese system of mandarinate. ${ }^{31}$ This liberal reform had been an attempt to tie the extension of suffrage to an elevation of the general level of education. The link between rational, positivist education in state schools and the promotion of liberalism would then have permitted the Liberal Party to gain control of local government. Unfortunately for the initiators, as with most electoral modifications, this short-term goal was not achieved. In 1884, the Catholic Party won an absolute majority in Parliament, and began an uncontested period of thirty years in power.

\subsection{Belgium 1893: plural voting under a majority system}

Je suis grand partisan de l'égalité de tous devant la loi. Je ne conçois pas l'égalité de tous pour faire la loi. (AUGUSTE BEERNAERT) ${ }^{32}$

L'alliance des catholiques avec le peuple contre la bourgeoisie voltairienne. (JOSEPH BARTHELEMY) $)^{33}$

A major step was taken ten years later. Massive strikes, incurring riots, police repression and deaths, forced Belgian Parliament to modify the 1831 constitution to extend parliamentary suffrage in $1893 .{ }^{34}$ The plural voting system was a compromise favoured by the moderate Catholic Cabinet Leader Auguste Beernaert (1829-1912), future Nobel

had lowered the censitary threshold for municipal elections. This resulted in Catholic victories in the major cities in Flanders. ibid 82. The introduction of local capacity suffrage, however, lead to a decrease in the number of local electors, from about 350000 to 136000 (62 800 held the degree required, the others passed a supplementary exam). ibid 192, 209.

${ }^{30}$ BARTHÉLÉMY (1912), 92. Likewise, in 1890, the Liberal party introduced a proposal for reforming art. 47 (old) of the Constitution, linking suffrage to 'savoir lire et écrire', as an absolute minimum threshold. ibid 267.

${ }^{31}$ BARTHÉLÉMY (1912), 117.

${ }^{32}$ Chamber of Representatives, 28 February 1893, quoted in ibid 210.

${ }^{33}$ ibid 334.

${ }^{34}$ ORBAN (1911), I, 36 ; LACHAPELLE (1911) 141-143; BARTHÉLÉMY (1912) 300-303. 
Peace Prize winner. ${ }^{35}$ Article 47 of the constitution foresaw that all male inhabitants above the age of twenty-five would have a single vote. Family fathers obtained a supplementary vote under certain conditions ${ }^{36}$, just as modest owners ${ }^{37}$. Finally, holders of a higher education degree benefitted from two supplementary votes. ${ }^{38}$ In total, no elector could have more than three votes.

As a consequence, the Belgian Workers' Party (founded in 1885) became the second-largest political group in the Chamber of Representatives at the 1894 parliamentary elections. ${ }^{39}$ The Liberal Party crashed down to third place. This was an unexpected consequence of the majority system. Belgium, since 1831, had a plurinominal majority system. From 1877 on, lists of candidates competed for all available seats in a constituency. ${ }^{40}$ Hence, the Liberals were eliminated by joint lists of Socialists and dissident progressive Liberals in traditional strongholds, such as Liège. After 1894, Liberal and Socialist Parties became allies in proposing the introduction of proportional representation. In case of a run-off between Catholics and Socialists, Liberal voters were obliged to side with one of these blocs, which led to the erosion of their party. ${ }^{41}$

\footnotetext{
${ }^{35}$ Léopold II and Auguste Beernaert (1920).

${ }^{36}$ Being at least 35 years of age, being married (or, in case of widowhood, having produced legitimate offspring) and, finally, acquitting a personal contribution of at least five francs. For details, see ORBAN (1911) I, 40.

${ }^{37}$ Owning an immovable property of 2000 francs, or receive a rent on movable property of at least 100 francs per year. See ibid I, 41.

${ }^{38} \mathrm{ibid}$ I, 44. Holders of a degree of higher education, either public (the State universities of Ghent and Liège) or private (the Catholic university in Leuven, or the Free University in Brussels), as well as electors assimilated to degree holders: students having completed a full secondary education, or having been admitted to university, as well as those exercising certain public positions, to be enumerated by the Electoral Law. The latter category allowed members of the Royal Academy, secondary school inspectors, catholic priests... to participate.

${ }^{39}$ PIERSON (1953).

${ }^{40}$ LACHAPELLE (1911) 132. At that time, 130000 male citizens were entitled to vote in parliamentary elections.

${ }^{41}$ ERRERA (1916) 153.
} 
In 1894, 853628 electors had one vote, 203678 could vote twice, and 223381 electors had three votes. In total, 1370687 voters controlled 2111127 votes. $^{42}$ The Catholic Party obtained 104 seats out of 152 in the Chamber of Representatives, the Liberal Party 20 and the Belgian Workers' Party $28 .{ }^{43}$ Ten years earlier, the country had counted just 124378 voters. ${ }^{44}$

\subsection{Belgium 1895: plural voting for local elections under a mixed, neo- corporatist system}

Le grand principe national de la poire coupée en deux. (GEORGES LORAND, 30 March 1895, Chamber of Representatives $)^{45}$

Auguste Beernaert's compromise was despised by the most conservative group within the Catholic Party, namely the Fédération des Associations et Cercles Catholiques. Beernaert had to resign after ten years as Cabinet Leader (1884-1894), ${ }^{46}$ and was succeeded by the conservative Jules de Burlet (1844-1897). The latter introduced a stringent reform of Frère-Orban's system of municipal capacity voting. Plural suffrage was extended to the municipal election, albeit with the possibility to add a fourth vote, increasing the gap between labourers (one vote) and wealthy landowners (four votes). The age threshold was raised to 30 years, excluding many potential left-wing voters. An additional requirement of three years of residence within the same municipality prevented the highly mobile group of labourers from fully participating.

\footnotetext{
${ }^{42}$ WILLEMS (1896), 8. However, in constituencies were the number of candidates was equal to the number of vacant seats, no election was held. This deprived the Catholics of a certain number of votes, whereas they still kept the seat. LACHAPELLE (1911) 150.

${ }^{43}$ LUYKX (1978), 208.

${ }^{44}$ BARTHÉLÉMY (1912) 305.

${ }^{45}$ Quoted in ibid, 640. Liberal MP for Virton-Neufchâteau. See Lauwers (2018).

${ }^{46}$ Conservative Catholics and part of the Liberal MPs rejected Beernaert's proposal of partial PR, limited to constituencies with at least 2 MPs to elect, keeping nine constituencies returning a single MP. LACHAPELLE (1911), 144. All 17 liberal MPs who rejected Beernaert's PR proposal were ousted at the following legislative elections. ibid 151 .
} 
Finally, in boroughs counting over 20000 inhabitants, supplementary seats were allotted to representatives of employers and workers. ${ }^{47}$ Ultramontanist ideas of corporatism could reinforce this anti-socialist buffer. ${ }^{48}$ Naturally, the Belgian Workers' Party decried this loi des quatre infamies ('Law of the four disgraces').

Most importantly for the present paper, the majority system was amended for local purposes. If a single list conquered the majority of all votes expressed, it would obtain all seats in the local council. However, if it failed to (which was the case in most larger towns), proportional representation (the D'Hondt system ${ }^{49}$ would be used in the second round. The Catholics hereby hoped to retain absolute power (without opposition) on the countryside, and divide their Socialist and Liberal opponents in the major cities. ${ }^{50}$ This first and biased introduction of PR at the local level nevertheless helped to institutionalise the method in Belgium. ${ }^{51}$

\subsection{Belgium 1899: proportional representation for parliamentary elections}

Était-il même prudent, de la part des catholiques, de conserver un mode de scrutin qui lui assurait sans doute des majorités écrasantes,

\footnotetext{
${ }^{47}$ ORBAN (1911) I, 69. This 'representation' of interests was even defended by Liberals in Belgium (Emile De Laveleye, Charles Buls), but ran counter to the main objection that interests in society could not be fixed anymore as they were under the Old Regime's system of guilds and corporations. The main objective of a system of interest representation is to offer a counterweight to the atomised and individual conception of citizenship and electoral participation. Its proponents hope that major electoral swings would be eliminated, giving rise to stable societal and political relations. Orban personally feared the irrevocable introduction of the class struggle in Parliament. See ibid I, 55-57.

${ }^{48}$ A socialist breakthrough at the local level was associated with the spectre of the Parisian Commune. In Belgium and France alike, socialist 'municipalisme' was a breakthrough strategy. HOUTTE (2014), 200.

${ }^{49}$ LACHAPELLE (1911) 165.

${ }^{50}$ A similar idea underpinned the proposal by Cabinet leader Vandenpeerenboom in 1899: PR would be reserved for the constituencies were Catholics had less chance to conquer the majority: Ghent, Antwerp, Brussels, Liège, Louvain, Charleroi and Mons. Ibid, 155. ${ }^{51}$ ERRERA (1916) 153.
} 
mais qui avait pour effet de supprimer brutalement le parti libéral? (GEORGES LACHAPELLE) $^{52}$

De Burlet's conservative law generated the risk that Catholics could be eliminated altogether from city councils, when Socialists and Liberals would constitute a single list and obtain the majority. This happened in Antwerp and Brussels in $1911 . .^{33}$ Yet, the majority system endangered the stability of the parliamentary system as a whole. Violent street protests, and even an invasion of Parliament, forced the Catholic Party's hand. Under pressure of an ad hoc-coalition of Socialists, Liberals and its own Christian Democrat wing, with the support of King Leopold II, the Catholic majority introduced proportional representation in $1899 .{ }^{54}$

Seats would be shared out in proportion to every political party's share of the vote. However, careful not to squander its domination in the countryside, the Catholic Party stuck to a system of relatively small constituencies, where only 2 to 3 seats were available. ${ }^{55}$ In rural

${ }^{52}$ LACHAPELLE (1911) 152.

${ }^{53}$ WILS (2017), 158. Errera notes that the 1895 lois des quatre infamies introduced PR for the first time in Belgium and contributed to the institutionalisation of the practice.

${ }^{54}$ Former Cabinet Leader Beernaert rose to the defence of PR in parliament. See Het Laatste Nieuws, 6 April 1898. An often-cited ratio for the introduction of PR is that 'on ajourne à jour indéterminé la dictature de la classe ouvrière pour la révolution sociale' (BARTHÉLÉMY (1912), 618). Proportional representation renders a Socialist absolute majority less likely. Hence the ideological opposition of Walloon far-left socialist MPs as Alfred Defuisseaux (1843-1901), who saw 'l'Infâme Proporz' as a treason of the socialist ideal of class warfare, and hoped to suppress it, once Universal Suffrage would have been in place. A second frequently mentioned motive is the wish to guarantee the representation of minorities in both the Dutch- and French-speaking provinces. Barthélémy linked this to a statement by Simeon Stern, president of the New York PR association, arguing that PR could have avoided the American Civil War. ibid 628 note 1. Proportional representation should not be confused with systems of guaranteed representation of minorities, which allow the elector to choose only a fraction of the seats available through a majoritarian system, reserving some seats to the minority party. This system was used in Spain, Brazil, Portugal and (incidentally) Britain and Italy. ORBAN (1911), I, 67.

55 LACHAPELLE (1911), 44. Orban considered districts with only two seats as problematic. In 1911, this was still the case for the sole district of Virton-Neufchâteau, whereas the districts of Hasselt, Tongres, Arlon, Turnhout, Thuin, Termonde, Audenaerde and Ypres returned 3 MPs. ORBAN (1911), I, 76. Recently (5 December 2007, 26 
areas, Socialists nor Liberals bothered to propose a list of candidates! ${ }^{56}$ Consequently, the Catholic Party obtained 86 seats out of 152 at the elections of 27 March 1900. A loss of 16, but still more than the recrudescent Liberal Party (33) and the Socialist Party (32) taken together. ${ }^{57}$

Proportional representation was introduced to soften the opposition between conservative Flanders, dominated by Catholics, and the increasingly more Socialist boroughs in the Walloon steel basin, a region which had developed significantly due to the Industrial Revolution. ${ }^{58}$ Paul Errera (1860-1922) $)^{59}$ notes in his Traité de droit public belge that the advent of the Socialist parliamentary group in 1894 was feared to bring about the disappearance of parliamentarism itself, just as it would undo the traditional bipartisan system of Catholics and Liberals. ${ }^{60}$ The perspective of facing solely the Socialists as opposition exposed the

November 2015), the Belgian Constitutional Court found that districts returning less than 4 MPs were unconstitutional. See BOUHON, JOUSTEN \& VROLIX (2018) 5.

${ }^{56}$ This reinforced the effect of the Jefferson/D'Hondt system, which tends to benefit major parties. GASSNER (1993), 8. It is often thought that the Catholic Party would have come under the ever greater influence of Christian Democrat (labour union) and Flemish Nationalist politicians. Recent work tends to nuance this, emphasising the enduring impact of conservatives: VAN VELTHOVEN (2014).

${ }^{57}$ Luykx (1978), 208.

${ }^{58}$ On 22 December 1899, at the proposal's final debate in the Belgian Senate, Catholic Senator and legal scholar Edouard Descamps (1847-1933) hoped that the representation (and expression) of ideas would be untangled from their previous sectarian link with societal groups, linguistic classifications, the opposition between city, industrial centres and countryside. Libon \& Nandrin (2016), 83-84. According to historian Lode Wils, proportional representation allowed the anti-Catholic Walloon movement to stop the flow of linguistic measures in Belgium until 1914. Wils (2019), 154, 158. Lachapelle, on the other hand, notes socialist resistance in Hainaut against the idea of PR, since this implied sharing part of the cake with other political parties. The General Council of the Belgian Workers' Party, however, rejected this objection. Lachapelle (1911), 161, 167.

${ }^{59}$ Professor at the Université libre de Bruxelles since 1896 (rector from 1908 to 1911), mayor of Uccle (1912-1921), member of the Royal Academy of Belgium (1919) and of the Israelite Consistory of Belgium. Velu (1994).

${ }^{60}$ Errera (1916), 153. 
dangers of the majority system. If the elector is forced to choose between two alternatives, the system logically leads to a victory of the other pole.

Paul Errera explains proportional representation as a 'Third Way' of representation, allowing to avoid the disadvantages of uninominal majority (which lead to the 'triomphe des médiocrités sur les hommes de grande valeur') ${ }^{61}$ and plurinominal majority systems (leading the elector to vote for candidates which he has not chosen himself) ${ }^{62}$.

Proportional representation allowed the coexistence of multiple parties, which softened the impact of lists. Errera points to the feeble majority at parliamentary elections in the district of Brussels in 1893. 18 seats at a stroke could shift due to a couple of hundred or even dozens votes. ${ }^{63}$ On the conceptual level, Errera explained proportional representation as a more adjusted and specific concept of the electoral function. ${ }^{64}$ First, Errera agreed that the majority rule - within Parliament - was indispensable. The minority had to acquiesce when a majority of representatives agree on voting a law. However, there was no fatality for the elector himself to see his choice evaporate when it did not conform to not that of the majority of the votes cast. In other words, a distinction between 'droit de décision', a corollary of the parliamentary function, and 'droit de représentation'. The latter is designed to help citizens exercise their part of national sovereignty, not to favour a specific government. ${ }^{65}$

\footnotetext{
${ }^{61}$ Ibid 152.

62 Ibid.

${ }^{63}$ Ibid 152 and 154. On the majority system: 'À cette époque, les journées électorales étaient littéralement des journées de bataille, qui parfois laissaient des blessés, sinon des morts ; elles offraient de vrais coups de hasard.' Further examples can illustrate the uncertainty provoked by the system: in 1878, the Catholic Party had 3232 votes more than its Liberal competitor, but lost the majority of seats in the Chamber of Representatives. In 1886, 24615 Catholic votes obtained 44 seats, whereas 23484 liberal votes (barely 1200 less) only 2 . The last elections under the censitary system gave the Liberals 34 seats with 52198 votes. The Catholics, who obtained only 6000 more votes, gained the double number of seats (68). Lachapelle (1911), 132, 138, 140.

${ }^{64}$ Errera (1916), 154.

${ }^{65}$ Lachapelle (1911), 49.
} 
Of course, Errera pursued, direct democracy, or legislation through referenda, could provide an alternative to the problem of representation: citizens would become legislators themselves. This would render the triumph of the 'yes' acceptable to those who opted for 'no'. ${ }^{66}$ Yet, within the representative system, the question of the weight accorded to an elector's choice would be one for 'mathematicians, not politicians' to resolve. ${ }^{67}$

${ }^{66}$ See the intervention of the Communist Deputy Henri Baranton (1895-1976) in the Chambre des Députés in 1927, who vowed to break the 'strike of the capitalists' (or speculation against left-wing policies) by having recourse to permanent referenda, rather than the 'systèmes grossiers, burlesques, primitifs' wherein men were given full powers to legislate during several years. J.O. D.P. CdD, 7 July 1927, col. 2389. The same criticism of representative democracy, albeit only in combination with the majority system, was given by the radical socialist Camille Pelletan (1846-1915) in June 1911: 'nous prétendons que le people n'a plus d'autre maître que lui-même. Et ce souverain, dont vous proclamez le droit imprescriptible, vous allez lui donner la parole une fois, une fois unique pendant douze heures tous les autre ans.' J.O. D.P. CdD, 2 June 1911, Col. 2501. Pelletan lamented the estrangement caused by the Parisian bubble vis-à-vis French electors: 'A peine élus, nous venons vivre ici, enveloppés par les préoccupations qui naissent dans l'air renfermé de nos couloirs, par les impressions, par les engouements de ce grand Molinchard qu'on appelle le Tout-Paris, probablement parce qu'il forme une portion très petite de la grande capitale et qu'il s'en sépare lui-même, par son dédain, d'un fossé infranchissable.' In the end, Pelletan leaned towards referenda as well: 'Je ne puis m'empêcher de trouver qu'un Parlement républicain, qu'un Parlement pénétré de la pensée de la souveraineté nationale fait un acte de folie, oui de folie véritable quand, pendant quatre ans, il renonce à jeter un coup de sonde dans ce qu'il y au fond de la pensée de ce pays.' In the same sense, Carré de Malberg likened proportional representation to an intermediate stage, bordering on direct democracy (Carré de Malberg (1922), II, 474). Finally, this brought Pelletan to condemn the Belgian system of political parties. Pelletan feared Jaures's insistence on l'esprit d'association would lead to situations whereby party insiders would dress a list, and thus 'enregimenter, endoctriner, régenter le suffrage universel!' (Ibid., col. 2052). Yet, one could also object, in Orban's words that 'committees and party headquarters' are still 'better than the almighty, plotting local clans in small constituencies'. Orban (1911) I, 49. On the latter aspect, see Marty, 2016.

${ }^{67}$ Orban (1911) I, 71; Errera (1916) 155. See Benoist (1895); Willems (1896); Ihl (2013), 387. For an example of a mathematician's work, see Lachapelle (1911). Lachapelle interviewed many French and Belgian protagonists, among which Charles Benoist, Jean Jaurès, Raymond Poincaré, Paul Deschanel, Jules Van den Heuvel, Eugène Goblet d'Alviella, Georges Lorand, Emile Vandervelde and Victor Van de Walle. See equally, on 
Proportional representation conforms best to the veracity of the electoral result. New parties can break through at the national level. If front bench candidates are elected as most prominent candidates on the list, lesser known homines novi can enter parliament through the system of suppléants or replacement candidates. ${ }^{68}$ Errera sincerely hoped that PR would undo the fixed relationship between a one-party parliamentary majority and its cabinet, and preferred 'des majorités d'un jour, ce qui nous changera des accords constants et souvent funestes' ${ }^{69}$

\section{French Debates Before 1914: 'Affranchir le suffrage universel' ${ }^{970}$}

Les inconvénients arithmétiques du régime majoritaire ne sont rien auprès de ses inconvénients moraux. (HENRI POINCARE) $)^{71}$

Le péril pour la République n'est point désormais du côté de la droite. Il est ailleurs. Il est dans l'immoralité des mœurs politiques et électorales qu'a perpétuées le scrutin d'arrondissement, dans les excès de la candidature officielle, dans les abus du favoritisme qui ont suscité un moment de révolte.'

(GEORGES LACHAPELLE on the 1910 elections for the Chambre des Députés $)^{72}$

PR as an alternative to direct democracy, or a means to save representative democracy: Rosanvallon (2010), 162.

${ }^{68}$ Introduced by the Law of 29 December 1899. Replacement candidates were considered to have been conditionally elected (awaiting the decease or resignation of an effectively elected MP). Orban (1911), I, 85; Errera (1916), 155. Errera further contends that the freedom of the elector had not been endangered by the advent of more organised mass parties: liberal and Catholic electoral associations had obtained such results in the past, that often candidates were elected 'sans lutte', eliminating thereby the possibility to compete for the minority. If 'l'électeur est vinculé dans son choix', these limitations are nothing but the sound consequence of societal organisation itself.

${ }^{69}$ Errera (1916), 156.

${ }^{70}$ Lachapelle (1911), 46.

${ }^{71}$ Foreword in ibid, IV.

${ }^{72}$ Ibid, 9. 
Notre ami Vandervelde a dit que s'il était socialiste français, il regarderait à deux fois et s'il était radical français, à trois fois, avant d'établir en France la représentation proportionnelle. (ERNEST BRETON, Chambre des Députés, 24 October 1909) ${ }^{73}$

Let's now turn to France. Activism for proportional representation generated leaflets, pamphlets and treatises in both Belgium and its neighbour country. The Ligue pour la représentation proportionnelle held meetings in Paris as well as in Brussels. ${ }^{74}$ Its advocates presented proportional representation as an advance of humanity in general. ${ }^{75}$ This idea was not utopian, since, at a mere five hour train ride from Paris, a more advanced and civilised system of seat distribution was already in operation. Personal exchanges with leading Belgian politicians

${ }^{73}$ Quoted in Barthélémy (1912), 621.

${ }^{74}$ The Belgian Ligue was founded in 1881, twenty-six years after the creation of a similar league in Geneva (Lachapelle (1911) 133; Orban (1911) I, 69). Future Cabinet leader Auguste Beernaert was a founding member, just as Victor D'Hondt and the political economist Emile de Laveleye (1822-1892). The Ligue pour la RP in France (1901) was more militant version of the Société pour l'étude de la RP, Paris, 1883 (RDILC 1884, 414 and Rosanvallon (2010) 154, 161, with inter alia Anatole Leroy-Beaulieu and Emile Boutmy. Raymond Saleilles equally proposed proportional representation in the 1900 world conference of comparative law (Sacriste, 2012, 357, 366 and Richard, 2017, 15). Foundation of an Italian Associazione per lo studio della rappresentanza proportionale in 1872 (RDILC 1872, 355). Hence Jaurès's remark in 1911 that PR had been a 'solitary conception of some academics' thirty years earlier. J.O. D.P. CdD, 2 June 1911, col. 2497. See also the Commission d'études du comité républicain de la R.P.: Anatole LeroyBeaulieu, Ernest Lavisse, Henri Poincaré. Lachapelle (1911) I-II. Foreword by Henri Poincaré: 'la cause de la représentation proportionnelle est gagnée auprès de tous ceux qui réfléchissent, pour peu qu'ils ne soient pas aveuglés par l'intérêt ou la passion', or in Lachapelle's own introduction: 'L'idée de la RP a été propagée en France, en Angleterre, en Italie, en Belgique, en Suisse, au Danemark - et on peut le dire dans tous les pays civilisés - par les esprits les plus éminents, par les serviteurs les plus désintéressés de la justice et du droit'. In 1885, an international conference convened in Antwerp, in the margins of the Universal Exhibition, proclaiming its adherence to the D'Hondt system as 'un mode pratique et rigoureux de réaliser la représentation proportionnelle' (Ibid, 137). The Association published its own journal, Représentation proportionnelle.

${ }^{75}$ Report on a lecture held before the Grand-Orient of France, Paris, 15 November 1901, in Le Siècle, 18 November (consulted on Retronews (BnF), last accessed 21 October 1901: https://www.retronews.fr/journal/le-siecle/18-novembre-1901/93/439973/1). 
and scholars fuelled French PR activism. ${ }^{76}$ Belgian Liberal MP Paul Janson ${ }^{77}$ was quoted in the Chambre des Députés, praising the election of Socialist and Liberal MPs 'infeudated' to the Catholics for centuries. ${ }^{78}$ Conservative Catholic politician Charles Woeste's denunciation of 'des foyers d'infection' through the disparate election of Liberal and Socialist MPs were eagerly noted by the French left. In his review of Barthélémy's elaborate study on the Belgian system, ULB law professor Maurice Vauthier (1860-1931) noted that many French observers were seeing proportional representation as the 'élixir merveilleux dont [...] un grand nombre de ses compatriotes, attend la régénération du régime electoral de la France'.$^{79}$ The absence of true universal suffrage in Belgium frustrated Socialist and Liberal attempts to do away with the Catholic absolute majority. ${ }^{80}$ Barthélémy would not have understood the profound nature of the confessional divide in Belgian politics and society. ${ }^{81}$

Legal historian and constitutional lawyer Adhémar Esmein (18481923) criticised proportional representation and favoured the 'simple'

${ }^{76}$ E.g. the founder of the French Ligue pour la RP, the journalist Yves Guyot's report on his visit to Brussels in November 1901, including meetings with Paul Janson (progressive liberal), Paul Hymans (traditional liberal) and Eugène Goblet d'Alviella in Le Siècle.

77 'Le Gambetta belge' Barthélémy (1912), 171.

78 Thomson in the Chambre des Députés, June 1911. J.O. D.P. CdD 2 June 1911, col. 2493.Esmein 1903.

79 Vauthier (1912) 565. On Vauthier (professor at the ULB since 1890, Rector 19031905, Member of the Royal Academy in 1907, Senator in 1921, Home Secretary in 1927, Minister for Science and the Arts 1927-1931), see Dekkers (1965).

${ }^{80}$ In the 1912 elections, the opposition fell 100000 votes short of beating the Catholic Party. Since this party dominated the Flemish provinces, Socialist and Liberal Frenchspeaking politicians felt as if they would never see the day on which Flemish domination would end. Supressing plural vote was thus - logically - high on the agenda for the opposition, and resented as great an injustice as the majority system. Vauthier (1912) 566567. Many observers judged the D'Hondt system reinforced the position of the Catholic party. The unity of the party would be assured thanks to the (slight) advantage given to the highest scoring list. Conversely, if Socialists and Liberals were condemned to form a 'cartel' against the predominance of the Catholic Party, more moderate Liberal voters would desert them. Lachapelle (1911) 111. For an excellent, simple and straightforward explanation of the difference between the D'Hondt system and the residuary meansystem, see Ibid, 113-117.

${ }^{81}$ Vauthier (1912), 567. 
and clear majority system. ${ }^{82}$ The root of Esmein's criticism resided in his equation of the right of representation to a collective right, of which the Nation was the bearer, and not the individual. Raymond Carré de Malberg (1861-1935) followed Esmein in stating that proportional elections were nothing but a purported disguise of a denaturation of the French representative system. Proportional elections were based on ideas of proportional representation, a necessary step in a descent towards direct government. Proportional representation would have created 'semirepresentative' government, where the monopoly of MPs to represent the nations was encroached on by individual voters. ${ }^{83}$

Errera (cf. supra) applied the distinction between the majority rule for the decisional function of MPs and proportional representation for their election. Carré de Malberg vehemently rejected this idea. From the moment of their election on, MPs should not worry about the 'diverse and heterogenous elements composing the electoral corps', but should see themselves as the 'exclusive organ of the nation by which it can express a will' ${ }^{84}$ The representatives of the nation did not have to worry to ensure a representation of all opinions or interests within the assembly, 'à aucun moment, pas même à l'époque des élections' ${ }^{85}$

Yet, the same political criticism as in Belgium existed in La Grande Nation. ${ }^{86}$ Gambetta chastised the disproportionate effect in seats of a handful of voters changing their minds. ${ }^{87}$ Thomson, by contrast, defended the 'majorité homogène et compacte' brought about by Universal Suffrage in France. There could not even be a Republic, if the will of the majority could not dominate! ${ }^{88}$ This argument is refuted by Errera in his treatise.

\footnotetext{
${ }^{82}$ Professor at the Paris Law Faculty, Deputy Director at the EPHE. See Sacriste (2012), 254-281.

${ }^{83}$ Carré de Malberg (1922), II, 478. Carré refuted the theory proposed by Saripolos 1899. See Beaud (2012) and Deroussin (2013), 167.

${ }^{84}$ Ibid II, 479.

${ }^{85}$ Ibid.

86 'Im Idealfall der Proportionalwahl gibt es keinen Besiegten, weil es keine Majorisierung gibt' Kelsen (1925) 348.

${ }^{87}$ Cited by Blaisot (republican) in 1927. J.O. D.P. CdD, col. 2298.

${ }^{88}$ Thomson, June 1911. J.O. D.P. CdD 2 June 1911, col. 2494.
} 
Yet, specific French circumstances explain Thomson's point of view: in his speech, he refers to the intrusion of a multitude of political parties, among which some might even be suspected to be unconstitutional. In other words, Thomson refers to the Legitimists, who favoured the restauration of monarchy in France. ${ }^{89}$ An 'imposing republican majority' was a necessity. Otherwise, no reform whatsoever would have been possible.

Léon Duguit (1859-1928) was more favourably inclined towards proportional representation, and did not envisage the opposition between representation and proportional elections..$^{90}$ In his Manuel de droit constitutionnel, he inventoried the frequent criticism of the French majority system. First, the arbitrary consequences following from the combination of a majority in parliament and the majority principle in the designation of MPs. The controversial law on the separation of Church and State had been voted by representatives in the Chambre des Députés assembling in total 2,6 out of 10 million French voters. ${ }^{91}$ Condorcet (1743-1794), ${ }^{92}$ Victor Considérant (1808-1893), ${ }^{93}$ John Stuart Mill (1806-1873) and Jean Jaurès (1859-1914), all three famous names, advocated replacing the inequitable majority system. Yet, Duguit thought the question was asked in the wrong way. Not proportionality between

\footnotetext{
${ }^{89}$ Ibid.

${ }^{90}$ This is explained by Guillaume Sacriste as part of the general tendency of provincial constitutional lawyers to challenge the core of the French Third Republic: parliamentary sovereignty and universal suffrage. Duguit proposed in 1895 to abolish the Sénat and replace it by a representation of interests, as an allusion on the 'esprit syndical'. Sacriste (2012) 447-450; Rosanvallon (2010), 117 ; Deroussin (2013), 160.

${ }^{91}$ Duguit (1907), 362. Garchery quoted supplementary numbers: 5159000 votes for elected MPs in 1902, but 5818000 for those who lost. In 1906: 5209000 votes for elected MPs, but 6383852 for non-elected candidates. In 1914, 57\% of French voters were not represented.

${ }^{92}$ Intervention by Senator Louis Martin (1859-1944), founder of the Ligue antiplébiscitaire, J.O. Sénat, 13 March 1913, p. 217.

${ }^{93}$ See also the left-wing republican Gaston Thomson (1848-1932)'s intervention in the Chambre des Députés in June 1911, on Girardin's proposal to create a collègue unique for the whole of France, giving every elector the right to choose his candidate over the whole of France. J.O. D.P. CdD 2 June 1911, col. 2492.
} 
political ideas as such, but a guarantee for the representation of minorities counted most. ${ }^{94}$

Arguments in favour of proportional representation did not only emerge from the voters' interest to be liberated from the yoke of local potentates, but also from deputies' own freedom. ${ }^{95}$ In 1927, the Communist Jean Garchery (1872-1957) called upon his colleagues to liberate themselves from the 'servitude' of their local constituency, in order to exercise their parliamentary voting right in dignity, with morality, preferring the battle of ideas to the battle of persons. ${ }^{96}$ 'Malheur à qui voudra se réfugier dans l'arrondissement': small constituencies were the political graveyard of big ideas. ${ }^{97}$

A second argument on MP's freedom was the 'ignoble second tour'. In the second round, French politicians were obliged to cater to the needs of other voters than those who supported them in the first round, leading to the sacrifice of 'ceux du premier tour qui pensent comme lui, mais dont il est sûr'.$^{98}$

The most eloquent advocate of proportional representation was Jean Jaurès (1859-1914). In 1910, the French legislative elections were won by the Radical-Republican-Socialist Party and the Socialist Republican Party, of which many members favoured PR. Jaurès (SFIO) challenged the idea that a majority of Frenchmen could be constituted by the addition of local majorities. ${ }^{99}$ According to Jaurès, the equal right of all citizens to control and direct human activity was the founding principle of sovereignty. The majority can only decide if is built on fundamentally equal individuals. Jaurès noted the marginal position of proportional

${ }^{94}$ Duguit (1907), 363.

${ }^{95}$ For a chronological overview of discussions in the Chambre des Députés up to the law of 12 July 1919: Esmein and Nézard (1921) 299-309.

${ }^{96}$ J.O. D.P. CdD 2 June 1911, col. 2387.

${ }^{97}$ HoutTe (2014), 184.

${ }^{98}$ Lachapelle (1911), V. See also Orban (1911) I, 49. PR would distort the 'nature of national representation', and 'destroy electors' freedom [...] compelled to through themselves in immoral coalitions or to abstain.'

${ }^{99}$ J.O. D.P. CdD 2 June 1911, col. 2495. 
representation only three to four decades earlier, and its remarkable rise in countries with an intense political activity. He attributed this rise to the 'esprit d'association', or the necessity to integrate individuals within social structures such as trade unions. ${ }^{100}$ This movement was essential! Without the esprit d'association, universal suffrage risked destroying itself through fragmentation in parliament. ${ }^{101}$ Proportional representation ought thus to generate political parties, or in Rosanvallon's words 'appréhender le pluralisme social sous les espèces du pluralisme des partis' ${ }^{102}$

Jaurès recalled that the growth of the French state had been a consequence of administrative centralisation. Local resistance had been broken during the French revolution. If the legislative branch of government allowed itself to be splintered in hundreds of small fiefs, the executive would wield excessive power. ${ }^{103}$ Proportional representation would arouse voters' attention: finally they would be free to vote for an idea, rather than for a local face. Furthermore, without regular reform, Jaurès warned, systems of freedom ('les régimes de liberté') would inevitably come to their end. Even if there would probably not be a majority for the socialisation of all individual property, he was persuaded that one could be found for a minimum programme of social reform. ${ }^{104}$

${ }^{100}$ Le Beguec (1986), 73. The Confédération Générale du Travail (CGT), until recently France's most prominent labour union, was founded in 1895, precisely in this era. Houtte (2014), 200. The CGT campaigned on the specific reforms Jaurès pleaded for, such as the eight hour-working day.

${ }^{101}$ Lachapelle (1911), 53-66. See in a similar vein, Belgian arguments pro PR and against the 'esprit de clocher': De Smaele (1999).

102 Rosanvallon (2010) 164; See Orban's defence of political parties: 'don't believe political parties would be a weakness and an illness of the modern state. They are both the condition and proof of a strong political life.' Orban further relies on Bluntschli to state that 'parties are constituted and blossom in a healthy nation, whereas factions are the sign of a sick society.' Orban (1911), I, 59; Kelsen (1925), 351. Kelsen, however, warned for sufficient democratic safeguards within political parties, in order to avoid the 'dictatorship' of party leaders.

${ }^{103}$ Jaurès, June 1911. J.O. D.P. CdD 2 June 1911, col. 2498.

${ }^{104}$ Detailed by Jaurès further on in his speech: $1^{\circ}$ an income tax, $2^{\circ}$ working men's pensions $3^{\circ}$ social insurance $4^{\circ}$ weekly mandatory rest for all workers $5^{\circ}$ restrictions on home labour. Jaurès thought these proposals infuriated many petty lobbies, capable of rigging 
Individual strife between local potentates should not divide political forces with a higher calling. ${ }^{105}$

When reacting to these arguments, equally put forward by Barthélémy ${ }^{106}$, Vauthier was not convinced of the impact PR had had on party organisation, nor on the focus on an elevated debating climate dominated by high ideas. To his interpretation, Belgium was locked in a linguistic crisis, which PR could not have prevented. ${ }^{107}$

PR was adopted in 1912 by the Chambre des Députés, but defeated in the French Sénat in 1913. The radicals of Georges Clemenceau (18411929) and Emile Combes (1835-1921) swung against the text adopted by the Chambre des Députés and dropped their support. ${ }^{108}$

\section{After the Great War: the end of the "Belgian Laboratory"}

In this section, the end of the "Belgian Laboratory" will be discussed after the Great War.

\subsection{Belgium 1918-1921: the advent of 'pure' PR for parliamentary election, and the defeat of the 'loi des quatre infamies'}

Belgium introduced Universal Suffrage under pressure. Contra constitutionem, the elections of November 1918 were organised without the double and triple voting system of 1893. Politically and morally, the government felt it impossible to discriminate against the one vote-electors who had risked or given their lives in the Great War, especially with

elections in small constituencies (arrondissements, as opposed to the département, the scale at which proponents of proportional representation in France saw the appropriate scale for fair elections). J.O. D.P. CdD 2 June 1911, col. 2498.

105 Jaurès believed that alcohol abuse in the West of France was due to the systematic lobbying of the local industry, and thought they would not be able to control parliament any more under proportional representation. J.O. D.P. CdD 2 June 1911, col. 2498.

${ }^{106}$ Vauthier (1912), 565; Barthélémy (1912), 715.

${ }^{107}$ See equally Wils (2017), 158-183.

${ }^{108}$ HouTte (2014), 374; Lachapelle, (1913). For the broader movement underpinning PR advocacy, see Marty (2013). 
the spectre of the Bolshevist Revolution in Russia in the background. ${ }^{109}$ Two million voters participated in the elections, without any distinction according to wealth or education. Consequently, the Catholic Party lost its absolute majority, opening the era of coalition government, where proportional representation represented justice between political parties. The Catholics came down to 73 seats out of 186 (a loss of 26 seats). The Socialists gained 30 seats and obtained 70 MPs in the Chamber of Representatives. The Liberal Party lost slightly, but maintained its representation. For the first time, five Flemish Nationalists were elected. ${ }^{110}$

The introduction of the one man, one vote-principle was not the only innovation in electoral law. First, the loi des quatre infamies was necessarily sacrificed to the exigencies of the Belgian Workers' Party. Second, the iniquitous small constituencies on the countryside had to become true territories of democracy. ${ }^{111}$

Municipal elections were held according to pure universal suffrage, including suffrage for women. ${ }^{12}$ The major reform of parliamentary elections consisted in allowing for the regrouping of surplus votes at provincial level. Seats were distributed first in constituencies. Yet, if it was not possible to attribute seats directly, the remaining seats were allotted to the parties with the highest number of remaining votes at a higher level. In total, the repartition of seats was conformable to what would have been the outcome if the election had taken place at the provincial level. Consequently, votes for Socialist, Liberal, Communist or Flemish Nationalist candidates in rural areas were not lost anymore, but counted together with those expressed in the provincial capital. Whereas

\footnotetext{
${ }^{109}$ Velaers (2009), 464-468. The new electoral law lowered the minimum age to 21, thus including soldiers aged between 21 and 25 .

${ }^{110}$ Luykx (1978), 291.

${ }^{111}$ Provinces of Luxembourg, West Flanders, Limburg, Namur. E.g. at the parliamentary elections of 1900 in Limburg, the Liberal party's share of the vote (1/6 of all votes) ought to have been sufficient to gain one seat out of the six seats available in the province. However, the Catholic party managed to conquer all seats in both districts, which required a third of the votes as minimum threshold.

${ }^{112}$ Female suffrage was opposed by the Socialist and Liberal parties, by fear of Catholic domination. Velaers (2009) 512, 566-568.
} 
the one man one vote-principle had killed off the Catholic absolute majority, the new system of apparentement, inspired by the Liberal MP Victor Van de Walle (1849-1927), ${ }^{113}$ assured an equitable distribution of seats between rural and urban areas. ${ }^{114}$ Hence, the 'effets détestables' of the D'Hondt system in small constituencies could be resolved. ${ }^{115}$

\subsection{France 1919: a conditional PR experiment}

France introduced proportional representation for the election of the Chambre des Députés with the law of 12 July $1919 .{ }^{116}$ This text was a compromise, out of fear of too much fragmentation in the representative landscape. Candidates obtaining the absolute majority of votes were automatically elected. Proportional representation only became applicable for those seats where no individual candidate had obtained an absolute majority. ${ }^{117}$ Furthermore, under certain conditions, the largest party

${ }^{113}$ VAN DE WALLE (1910). Kelsen warned against small territorial constituencies, leading to a deprivation of seats for smaller parties, even under a formal PR system: 'Tatsächlich führt es zu sehr bedeutenden Störungen der Proportionalität des Gesamtergebnisses, wenn bei der Parlamentswahl [...] und das Proportionalitätsprinzip nur innerhalb der territorialen Wahlkörper Platz greift'. KELSEN (1925), 351. The Belgian system between 1899 and 1921 is an illustration of this risk. ibid.

${ }^{114}$ Law of 22 October 1919. Velaers (2009); Verleden (2015), 61.

${ }^{115}$ Words of Gaston Thomson, Chambre des Députés, J.O. Chambre des Députés, 22 June 1911, col. 2493. See also Bouhon, Jousten and Vrolix (2018).

${ }^{116}$ Loi portant modification aux lois organiques sur l'élection des députés et établissant le scrutin de liste avec représentation proportionnelle, 12 July 1919, Bulletin des Lois 1919, II, 2096. This distributed seats in the Chambre des Députés according to the outcome of a division of a department's population by 75000 (art. 2), with a minimum of 3 MPs per department (art. 3). This contrasted with the previous unequal representation, as exemplified by the 3.446 electors of Barcelonette in 1910, who elected one MP, just as those of Versailles, with 36.472, or the tenfold of registered voters (Lachapelle (1911) 15). Art. 10 instated the calculation of a division number (outcome of the votes cast, divided by the number of MPs to elect). Lists obtained seats proportionate to the result of this calculation. The remaining seats were attributed following la plus forte moyenne. No seats were attributed if less than half of the registered electors turned up, or if no list obtained the electoral division number (art. 13).

${ }^{117}$ Carré de Malberg (1922) II, 469, note 1. Esmein and Nézard (1921), 310. 
received a bonus. ${ }^{118}$ Hence, Carré de Malberg contended that individual voters would have acquired the quality of organ of the nation, which he reserved for elected MPs only. ${ }^{119}$

In the 1925 edition of his Allgemeine Staatslehre, the Austrian constitutional lawyer Hans Kelsen ironically remarked that the shift away from Carré de Malberg's idea of the nation as a collective sovereign had not always been evident ('selbstverständlich'). Kelsen recognised Carré de Malberg's reasoning was correct: proportional representation implied that not the Gesamtwählerschaft (all voters), but Teilkörper (parts of the electorate) became the bearers of the right to elect (droit d'élire). It was thus highly probable that proportional representation would increase the degree of Unmittelbarkeit (direct link) between individual voters and government. ${ }^{120}$ Thanks to proportional representation, the definition of these subgroups was not a matter of 'unnatural' territorial criteria, but of an affiliation between persons agreeing on the same political ideas (alle Personen der gleichen politischen Überzeugung). ${ }^{121}$

Carré de Malberg focused excessively on an extreme case ('ideeller Grenzfall'), whereby the representative system as such would be destroyed. Kelsen fully adhered to Errera's distinction between the operation of the majority rule for decisions made in parliament, on the one hand, and every citizen's right to be represented, on the other hand. Proportional representation was a consequence of the 'individualistische Prinzip der Freiheit'. All minorities in society, by their mere existence, exert an influence on political decisions. The narrower a political majority becomes, the more it will be inclined to build its decisions on compromise. As a consequence, proportional representation ensures the majority will not abuse of its power, to let 'die Wille der Mehrheit schrankenlos

\footnotetext{
${ }^{118}$ The number of preference votes expressed could result in the attribution of remaining seats to candidates on the largest list. Esmein and Nézard (1921), 317.

${ }^{119}$ Carré de Malberg (1922), II, 480. For Carré, the 'droit de vote' ought to be distinguished from the 'droit d'élire', which only belonged to the corpus of active citizens, the only 'organe electoral de l'Etat'. Ibid II, 481.

${ }^{120}$ Kelsen (1925) 349.

${ }^{121}$ Ibid, 348.
} 
über den der Minderheiten herrschen'. ${ }^{122}$ Minorities could not prevent the majority from acting according to its wishes, but proportional representation offered them the possibility to come 'unwesentlich näher' (almost unimaginably close) to a culture of compromise and pacification.

\subsection{France 1925-1927: the triumph of majoritarian orthodoxy}

After the return to the majority system, Léon Duguit, who had defended 'PR' before World War One, showed himself very critical of proportional representation. In his course on public law professed at the University of Cairo in 1926, he doubted whether the concept would be compatible with national sovereignty at all, and stated that Belgium had 'no majority left whatsoever'. ${ }^{123}$ This a reference to the severe financial tensions during the 1925-1926 government of Socialists and Catholics, which was brought down by speculation. ${ }^{124}$ However, one could also use the opposite argument, as Jaurès did during the 1912 debate, at the apex of the 'mouvement proportionnaliste' of 1906-1913: the majority system in France had not assured stable majorities. ${ }^{125}$ Duguit's rejection in 1926 is rather surprising. Three years earlier, the 1923 edition of his Traité de droit constitutionnel, echoed Carré de Malberg's preference for the term proportional 'election'. However, Duguit added that proportional 'representation' in itself was an ill-conceived term, since a proportional distribution of seats did not necessarily entail a new theory of representation or of national sovereignty. One could infer that Duguit did not consider PR incompatible with the republican idea of national sovereignty. ${ }^{126}$

${ }^{122}$ Ibid, 349. See also Baumert (2013), 11-12.

123 'Pour ma part j'ai été un fervent du système proportionnel. On se demande, et je me demande aujourd'hui si, à côté d'avantages évidents, il n'a pas de graves inconvénients, s'il n'aboutit pas, comme en Belgique, à la suppression dans les assemblées politiques d'une majorité de gouvernement, indispensable pour que la machine parlementaire puisse fonctionner.' Duguit (1926), 230.

${ }^{124}$ Matheve (2016), 271-272.

125 'Majorities can crumble with any system, causing any Government to seek support from various groups or parties'. Orban (1911) I, 130.

${ }^{126}$ Duguit (1923), III, 571. 
One year after Duguit's Cairo lectures, the Chambre des Députés opted to scrap proportional representation with the law of 21 July 1927 , with y a very thin majority (295 against 265). ${ }^{127}$ The return to the majority system was defended in an ulterior debate by Thomson. He stated in the Chambre des Députés that the majority system had been conformable to the 'génie même de notre regime politique et parlementaire' ${ }^{128}$, ever since the introduction of universal suffrage in $1848 .{ }^{129}$ Yet, the association of proportional representation and justice did not disappear with the wiping out of the system in 1925, as its multiple resurrections indicate. ${ }^{130}$ The republican Blaisot (1881-1945) argued that the 'justice électorale' was still an ideal cherished by the majority of his compatriots. ${ }^{131}$

\section{Conclusion}

From 1883 to 1921, the Belgian electoral system underwent systemic changes, designed to adapt representative institutions to the advent of universal suffrage and end the disenfranchisement of at least the male half of the adult population. An elitist well-off group of at most 100000 electors could no longer embody the collective national will. The parallel development of arguments on proportional representation in France, within the broader international 'élan proportionnaliste' of the later $19^{\text {th }}$ century, ${ }^{132}$ is striking. Parisian defenders of the republican regime staunchly opposed the introduction of this reform up to the Great War, whereas Belgian conservatives bowed fourteen year earlier, admitting PR, however without introducing the one man one voteprinciple, and without corrections in district size.

\footnotetext{
${ }^{127}$ Erhard \& Passard (2019), 14-17.

128 J.O. D.P. CdD 5 July 1927 , col. 2288.

${ }^{129}$ This refers back to the Third Republic's interpretation of Universal Suffrage after the fall of the Second Empire, see on this subject Prelot (2013).

${ }^{130}$ Le Beguec (1986), passim.

${ }^{131}$ J.O. D.P. CdD 2 June 1911, col. 2298.

132 Rosanvallon (2010), 156.
} 
Proportional representation was defended across borders by activists and legal scholars using the tautological moral slogan of 'justice and equality'. Yet, 'equality' in electoral affairs did not necessarily imply the one man-one vote principle (in the Belgian case), nor a right of mimetic representation (in the French case). Proponents and opponents of PR could conceive of alternative definitions of justifiable differences in treatment. For Carré de Malberg, equality in voting was restricted to 'l'aptitude au vote', and not applicable to the consequences of a vote cast, 'ceux-ci peuvant demeurer négatifs pour les électeurs qui forment la minorité'. ${ }^{133}$

Before the Great War, caught between conservative Germany, where the 1871 constitution still consecrated monarchical sovereignty ${ }^{134}$ and progressive, secular France, where left-wing and republican governments were feared as a factor of political instability in Europe, Belgium steered a middle course with experiments in its electoral 'laboratory'. Yet, due to the transnational constitutional and democratic reverberations of the Great War, the characteristic of 'justice'135 attached to PR would truly emerge, to transform the country profoundly.

In the long run, proportional representation had massive consequences for the operation of the Belgian political system. The country's culture of pacification gradually required the representation of all minorities, across the linguistic divide. Tensions between regions and linguistic communities are resolved in federalism (1970), tensions between employers and employees gave rise to a complex system of corporatist social negotiations (1919), tensions between Catholics and non-Catholics resulted in important pacts on schools (1959) and cultural life (1973). ${ }^{136}$ The increasing devolution of competences (1970, 1980, 1988, 1993, 2001, 2012) has entrenched PR-pacification mechanisms

${ }^{133}$ Carré de Malberg (1922), II, 481.

${ }^{134}$ In 1923, Duguit stated that the patrimonial idea of the state had ended in 1919. Yet, he still distinguished the German conception of a state based on Herrschaft and corporation (Jellinek), from the French idea of the nation as carrier of state sovereignty, exercised through representatives. Duguit (1923), 460.

${ }^{135}$ I borrow these expressions from political scientist Vedel (1978), 246.

${ }^{136}$ Witte, Meynen and Luyten (2017). 
within each constituent entity of the Belgian state. In that sense, the introduction of PR in 1899 was the most fundamental reform of the Belgian political system, the consequences of which reached further than its initiators could have imagined.

\section{References}

BARTHÉLÉMY, Joseph. L'organisation du suffrage et l'expérience belge. Suffrage censitaire, capacitaire, universel, suffrage plural, vote obligatoire, sincérité des opérations électorales, scrutin de liste, scrutin uninominal, représentation des intérêts, représentation proportionnelle. Paris: Giard \& Brière, 1912.

BAUMERT, Renaud. Kelsen, lecteur critique de Rousseau: de la volonté générale à la volonté collective. Jus Politicum, [s.l.], n. 10, 2013. Available in: http://juspoliticum.com/uploads/pdf/JP10-VG-Baumert PDF.pdf. Access in: $1^{\circ}$ Aug. 2020.

BEAUD, Oliver. Fragments d'une théorie de la citoyenneté chez Carré de Malberg. Jus Politicum, [s.l.], v. 8, p. 26-55, 2012. Available in: http://juspoliticum. com/uploads/pdf/JP8_Beaud_PDF_corr01.pdf. Access in: $1^{\circ}$ Aug. 2020.

BENOIST, Charles. De l'organisation du suffrage universel - IV: la représentation proportionnelle des opinions. Revue des Deux Mondes, [s.l.], p. 760-781, 1895.

BLACHÈR, Philippe. L'étendue du suffrage universel sous la II ${ }^{\mathrm{e}}$ République. Revue française d'histoire des idées politiques, [s.l.], p. 257-268, 2013. DOI: 0.3917/rfhip.038.0257.

BOUHON, Frédéric. Oscar Orban (1862-1926) - Le Dicey du Play pays. In: HEIRBAUT, D. et al. (ed.). Deux-centième anniversaire des Facultés de droit de Gand et Liège: Tweehonderd jaar rechtsfaculteiten Gent en Luik. Brugge: Die Keure, 2019. p. 92-95.

BOUHON Frédéric; JOUSTEN, Andy; VROLIX, Zoé. Les circonscriptions électorales du Parlement wallon. Courrier hebdomadaire du CRISP, [s.l.], n. 2.401-2.402, p. 5-100, 2018. DOI $10.3917 /$ cris. 2401.0005 
BRANDENBURG, Heinz. Tactical voting in the EP Elections. LSE British Politics and Policy Blog, 17 May 2019. Available in: https:// blogs.lse.ac.uk/politicsandpolicy/ep-elections-tactical-voting/. Access in: 21 Oct. 2019.

CARRÉ DE MALBERG, Raymond. Contribution à la théorie générale de l'État, spécialement d'après les données fournies par le droit constitutionnel français. Paris: Sirey, 1922.

COHENDET, Marie-Anne et al. Une dose de proportionnelle: pourquoi? Comment? Laquelle? Terra Nova, Paris, 19 March 2018. Available in: http://nova.fr/rapports/une-dose-de-proportionnelle-pourquoi-commentlaquelle. Access in: 3 Nov. 2019.

DEKKERS, René. Vauthier (Maurice): Biographie Nationale. Bruxelles: Bruylant, 1965. v. 33-Suppl (V). col. 711-716.

DEROUSSIN, David. L'idée corporative saisie par les juristes. Les Études sociales, [s.l.], p. 147-185, 2013/1.

DE SMAELE, Henk. Politiek als hanengevecht of als cerebraal systeem. Ideeën over politieke representative en de invoering van de evenredige vertegenwoordiging in België (1899). BMGN - Low Countries

Historical Review, [s.l.], v. 114, p. 328-357, 1999. DOI: 10.18352/ bmgn-lchr.4999.

DHONDT, Pieter. Un double compromis: enjeux et débats relatifs à l'enseignement universitaire en Belgique au XIXe siècle. Gent: Academia Press, 2012.

D’HONDT, Victor. Système Pratique et Raisonné de Représentation Proportionnelle. Bruxelles: Muquardt, 1882.

DUGUIT, Léon. Leçons de droit public général faites à la Faculté de Droit de l'Université égyptienne pendant les mois de Janvier, Février et Mars 1926. Paris: De Boccard, 1926.

DUGUIT, Léon. Manuel de droit constitutionnel. Paris: Albert Fontemoing, 1907. 
DUGUIT, Léon. Traité de droit constitutionnel. Paris: De Boccard, 1923.

ERHARD, Thomas; PASSARD, Cédric. The politics of electoral system choice in a context of democratization. Electoral reform and institutional change in the French Third Republic (1870-1940). Parliaments, Estates and Representation, [s.l.], p. 59-77, 2019. DOI: 10.1080/02606755.2019.1624405.

ERRERA, Paul. Traité de droit public Belge: droit constitutionel droit administratif (premier fascicule. Paris: Giard \& Brière, 1916.

ESMEIN, Adhémar. Eléments de droit constitutionnel. Paris: L Larose, 1903.

ESMEIN, Adhémar; NÉZARD, Henry. Éléments de droit constitutionnel français et comparé, T. 2: Le droit constitutionnel de la République française. Paris: Sirey, 1921.

GASSNER, Marjorie. Représentations proportionnelles. Système électoral belge ou délégations biproportionnelles. Courrier hebdomadaire du CRISP, [s.l.], n. 1.395, p. 1-25, 1993.

GILISSEN, John. Le régime représentatif en Belgique depuis 1790. Bruxelles: La Renaissance du Livre, 1958.

GOBLET D'ALVIELLA, Eugène. La Représentation Proportionnelle en Belgique: Histoire d'une Réforme. Bruxelles: Weissenbruch, 1900.

HEIRBAUT, Dirk; STORME, Matthias E. The Belgian Legal Tradition: From a Long Quest for Legal Independence to a Longing for Dependence? In: DIRIX, E.; LELEU, Y. H. (ed.). The Belgian reports at the Congress of Utrecht of the International Academy of Comparative Law. Bruxelles: Bruylant, 2006. p. 3-43.

HOUTE, Arnaud-Dominique. Le triomphe de la République, 18711914. Paris: Éd du Seuil, 2014.

IHL, Olivier. Sur les origines de la revendication proportionnelle. Revue Française D'histoire des Idées Politiques, [s.l.], p. 367-388, 2013/2. DOI: $10.3917 /$ rfhip.038.0367. 
KELSEN, Hans. Allgemeine Staatslehre. Berlin: J. Springer, 1925. LACHAPELLE, Georges. La Représentation Proportionnelle en France et en Belgique. Paris: Félix Alcan, 1911.

LACHAPELLE, Georges. La représentation proportionnelle et la crise ministérielle. Revue Politique et Parlementaire, [s.l.], p. 5-15, 10 Apr. 1913.

LAMBERTS, Emiel; LORY JACQUES (ed.). 1884: un tournant politique en Belgique. Bruxelles: FUSL, 1986.

LE Beguec, Gilles. La représentation proportionnelle: Cent ans de controverses. Vingtième Siècle, [s.l.], p. 67-80, 1986.

LESAFFER, Randall; VAN ERP, Beatrix (ed.). In the Embrace of France: The Law of Nations and Constitutional Law in the French Satellite States of the Revolutionary and Napoleonic Age (1789-1815). Baden-Baden: Nomos Verlag, 2008.

LAUWERS, Nathan. Georges Lorand (1860-1918): een transnationale progressieve liberaal. Brussels: ASP, 2018.

LIBON, MICHÈLE; NANDRIN, Jean-Pierre. De Senaat 1893-1918. In: Laureys, V.; Van den Wijngaert, M.; Velaers, J. (ed.). De Belgische Senaat: een Geschiedenis. Tielt: Lannoo, 2016. p. 59-88.

LUYKX, Theo. Politieke Geschiedenis van België. Amsterdam: Elsevier 1978.

MARTINEZ, Gilles. Joseph Barthélémy et la crise de la démocratie libérale. Vingtième Siècle - Revue D'histoire, [s.l.], v. 59, p. 28-47, 1998.

MARTY, Thomas. De l'espace électoral à son decoupage:

circonscriptions uninominales et circonscriptions de listes sous la Troisième République française. Norois, [s.l.], v. 226, p. 91-106, 2013.

MARTY, Thomas. Une histoire sociale de la réforme électorale sous la Troisième République: mobilisations politiques et expertise électorale - la question de la représentation proportionnelle. Paris: Fondation Varenne, 2013. 
MATHEVE, Niels. Tentakels van de macht: elite en elitenetwerken in en rond de Belgische tussenoorlogse regeringen (1918-1940). Kortrijk: INNI, 2016.

ORBAN, Oscar. Le droit constitutionnel de la Belgique. Liège: $\mathrm{H}$ Dessain, 1911.

PANTENS, A. Le citoyen belge: éléments de droit constitutionnel, institutions provinciales et communales, organisation judiciaire, instruction publique, régime électoral aperçu des lois politiques et ouvrières. Bruxelles: Balat, 1901.

PIERSON, Marc Antoine. Histoire du socialisme en Belgique. Bruxelles: Institut Emile Vandervelde, 1953.

PRELOT, Pierre-Henri. Le Suffrage Universel dans la République. Les débats parlementaires 1871-1875. Revue Française D'histoire des Idées Politiques, [s.l.], p. 305-328, 2013. DOI: 10.3917/rfhip.038.0305.

RÉMOND, René. La République souveraine: la vie politique en France 1878-1939. Paris: Pluriel, 2013.

SAULNIER, Frédéric. Joseph-Barthélemy 1874-1945: la crise du constitutionnalisme libéral sous la IIIe République. Paris: LGDJ, 2004.

SOLEIL, Sylvain. Le modèle juridique français dans le monde une ambition, une expansion, XVI $\mathbf{I}^{\mathrm{e}} \mathbf{X I X}^{\mathrm{e}}$ siècle. Paris: IRJS Ed., 2014. ROSANVALLON, Pierre. Le peuple introuvable: Histoire de la représentation démocratique en France. Paris: Gallimard, 2010.

ROUVILLOIS, Frédéric. Se choisir un modèle: Michel Debré et le parlementarisme anglais en 1958. Revue Française D'histoire des Idées Politiques, [s.l.], p. 347-366, 2000.

SACRISTE, Guillaume. La république des constitutionnalistes: professeurs de droit et légitimation de l'État en France, 1870-1914. Paris: Presses de Sciences Po, 2012.

SARIPOLOS, Nicolas. La démocratie et l'élection proportionnelle. Paris: Rousseau, 1899. 
VANDER VORST-ZEEGERS, J. Le 'Journal de Bruxelles' de 1871 à 1884. Louvain: Nauwelaerts, 1965.

VAN DER SMISSEN, E. (ed.). Léopold II et Beernaert: d'après Leur Correspondance Inédite de 1884 a 1894. Bruxelles: Goemaere 1920.

VAN VELTHOVEN, Harry. Scheurmakers en carrièristen: de opstand van christendemocraten en katholieke flaminganten 1890-1914. Kapellen: Pelckmans, 2014.

VAUTHIER, Maurice. Notice bibliographique: Joseph Barthélémy, L'organisation du suffrage et l'expérience belge. Revue de Droit International et de Législation Comparée, [s.l.], p. 564-568, [1912].

VELAERS, Jan. Albert I: Koning in Tijden van Oorlog En Crisis, 19091934. Tielt: Lannoo, 2009.

VERLEDEN, Frederik. De vertegenwoordigers van de natie in partijdienst: de verhouding tussen de Belgische politieke partijen en hun parlementsleden (1918-1970). Kortrijk: Inni, 2015.

VAN DE WALLE, Victor. La Représentation Proportionnelle intégralement appliquée aux élections législatives. Bruxelles: du Progrès - V. Feron, 1910)

VAN GOETHEM, Herman. De Taaltoestanden in het VlaamsBelgisch Gerecht 1795-1935. Brussel: Paleis der Academiën, 1990.

VEDEL, Georges. Réflexions sur la représentation proportionnelle. Commentaire, [s.l.], p. 245-260, 1978.

VELU, Jacques. ERRERA, Paul. Nouvelle biographie nationale.

Bruxelles: Académie Royale des Sciences, des Lettres et des Beaux-Arts de Belgique, 1994. T. III, p. 165-166.

WILLEMS, Pierre. La Représentation Proportionnelle et son application aux élections législatives du 14 Octobre 1894. Gand: Van Doosselaere, 1896.

WILS, Lode. Frans van Cauwelaert: Politieke Biografie. Deurne: Doorbraak, 2017. 
WILS, Lode. Verleden en toekomst van een natie. Wetenschappelijke Tijdingen, [s.l.], v. 78, p. 145-165, 2019.

WITTE, Els; MEYNEN, Alain; LUYTEN, Dirk. Histoire politique de la Belgique: de 1830 à nos jours (Transl. N. Barbar and O. Préaux). Bruxelles: Samsa, 2017.

Frederik Dhondt is Assistant Professor in legal and political history at the Vrije Universiteit Brussel, and director of the Research Group Contextual Research in Law (CORE). He is a lawyer (Ghent) and historian (Ghent/Paris), and has been a visiting researcher in Frankfurt, Heidelberg and Geneva. From 2016 to 2020, he was Visiting Lecturer in legal and political history at the University of Antwerp. He equally is a voluntary research associate at Ghent University (Legal History Institute/GRILI). His research interests concern the history of international law and constitutional law in the eighteenth and nineteenth centuries.

E-mail: frederik.dhondt@vub.be

Professional address: Office 4B312, Pleinlaan 2, 1050 ELSENE (Brussel), Belgium.

ORCID: https://orcid.org/0000-0001-9999-5658. 